\title{
ДОСВІД СТВОРЕННЯ ТА ВИКОРИСТАННЯ НАВЧАЛЬНИХ ФІЛЬМІВ ПРИ ВИКЛАДАННІ ГІГІЄНИ У ВИЩИХ МЕДИЧНИХ НАВЧАЛЬНИХ ЗАКЛАДАХ
}

\author{
Т. О. Перцева, О. А. Шевченко, С. В. Зимник, Н. І. Рублевська, С. А. Щудро, \\ Л. В. Григоренко, О. П. Штепа, Ю. С. Крамарьова, В. В. Зайцев, М. В. Дзяк, \\ О. О. Кулагін
}

ДЗ “Дніпропетровська медична академія МОЗ України”

\section{EXPERIENCE OF CREATION AND USING THE EDUCATIONAL FILMS WHEN TEACHING HYGIENIC IN THE HIGNER MEDICAL EDUCATIONAL INSTITUTIONS}

\author{
T. O. Pertseva, O. A. Shevchenko, S. V. Zymnyk, N. I. Rublevska, S. A. Shchudro, \\ L. V. Hryhorenko, O. P. Shtepa, Yu. S. Kramariova, V. V. Zaitsev, M. V. Dziak, \\ O. O. Kulahin
}

State Establishment “Dnipropetrovsk Medical Academy of MPH of Ukraine”

\begin{abstract}
У статті обговорюється питання дефіциту аудиторних годин для викладання гігієни на випускаючих кафедрах медичних ВНЗ та обгрунтовується доцільність використання допоміжних наочних посібників - відеофільмів. 3 власного досвіду кафедри гігієни та екології Дніпропетровської медичної академії пропонується алгоритм створення навчальної відеопродукції. Надаються конкретні практичні рекомендації для авторів при обранні теми, створенні сценарію, організації знімального процесу, монтажу та озвучування навчальних відеофільмів.

The article was focused on the applying of the auxiliary visual video films during Hygienic disciplines training in the higher medical institutions postgraduate departments in the conditions of shortening academic hours. The experience of Dnipropetrovsk Medical Academy Hygiene and Ecology Department could provide us recommendations towards educational video films new algorithm of creation. Specific practical recommendations were carried out for authors at the hygienic theme providing, scenario creation, organization of camera work activity, editing and sound of the educational videos.
\end{abstract}

Вступ. Реформування системи вищої медичної освіти в Україні [1], разом з опануванням трансферних стандартів ЄС та впровадженням кредитномодульої моделі організації навчального процесу, передбачає також скорочення 31 вересня 2015 р. аудиторного навантаження студентів медичних факультетів з теперішніх 6700 до 5500 годин за шість років навчання. У зв'язку з цим ще більший відсоток матеріалу навчальних програм з окремих дисциплін переноситься на самостійне вивчення, а аудиторний час для опанування багатьох складних тем скорочується до критичного. Для забезпечення прийнятної якості підготовки лікарів загальної практики, педіатрів, гігієністів-епідеміологів в нових умовах організація навчального процесу на випускаючих кафедрах має бути максимально

\footnotetext{
() Т. О. Перцева, О. А. Шевченко, С. В. Зимник та ін.
}

ефективною та стимулювати розумову працездатність студентів, формування їх понятійного апарату, здатність до аналітичного мислення, в т. ч. шляхом застосування аудіовізуальних засобів - навчальних відеофільмів [2]. За відсутності єдиного національного центру з випуску подібної продукції у багатьох вищих медичних навчальних закладах ця робота здійснюється на ініціативній основі. Публікуючи цей матеріал, ми мали за мету поділитись досвідом створення навчальних відеопосібників на кафедрі гігієни та екології ДЗ “ДМА МОЗ України”, що $є$ випускаючою для студентів за фахами “Лікувальна справа”, “Педіатрія”, “Медико-профілактична справа” та здійснює післядипломну підготовку лікарівінтернів і практичних лікарів-гігієністів. Наразі в доробку кафедри п'ять навчальних відеофільмів, затверджених ЦМК МОЗУ в якості посібників для студентів ВMHЗ III-IV рівнів акредитації. 
Основна частина. Нижче наведені декілька практичних рекомендацій, які допоможуть колективам профільних кафедр створювати корисні навчальні відеоматеріали з мінімальним залученням коштів та складного технічного обладнання.

Обрання теми. При обранні теми фільму доречно врахувати наступне: а) тема має бути досить складною для самостійного засвоєння (у випадку з гігієнічними дисциплінами це теми, що вимагають відповідних знань зі суміжних медичних та немедичних галузей - інженерії, архітектури, фізики і т. п.); б) має бути показовим та доступним для зйомок предмет вивчення - окремий об'єкт (підприємство, лікувальна установа, ін.) або відповідний процес (технологічна операція, лікувальна процедура, ін.). Приклад: при створенні відеофільму “Організація системи поводження з медичними відходами в сучасних ЛПЗ та профілактика шпитальних інфекцій” ми мали змогу фільмувати окремі ланки організації інфекційного контролю у ЛПЗ диспансерного типу, в т. ч. планувальні, архітектурні, інженерно-технічні, організаційні заходи, а також технологічний процес високотемпературного спалювання медичних відходів на сучасному сертифікованому устаткуванні - печі-інсенераторі виробництва Франції.

Сценарій. При створенні сценарію почніть 3 того, що саме ви маєте продемонструвати відеорядом фільму та розбийте його на декілька окремих змістових частин, кожна з яких також може містити окремі фрагменти, плани, аж до конкретизації руху відеокамери. Приклад: асептична обробка рук персоналу (крупний план - рукомийник з ліктьовим краном, ємності з асептичним засобом, рідким милом, засобами для пом'якшення шкіри рук, разовими рушниками; камера наближається та послідовно зупиняється на окремих предметах за технологією обробки шкіри). Під кожен відеоепізод пропишіть текстовий коментар, який має бути доволі стислим, доповнюючи та роз'яснюючи те, що він демонструє. Не переобтяжуйте вербальний супровід зайвою цифровою інформацією, назвами нормативних документів, додатковими посиланнями на літературні джерела, він має допоміжне значення та тільки коментує побачене. 3 нашого досвіду в межах дво-тригодинної аудиторної теми тривалість відеофільму може складати не більше 15-18 хвилин, з яких коментар відеоряду займає 80-85 \% від загального часу.

Зйомки. Заздалегідь погодьте всі деталі процесу з задіяними сторонами та сплануйте черговість зйомок окремих епізодів за сценарієм. Не даючи порад щодо загальних основ операторської справи, зауважимо, що для завдань навчального відеофільму може бути придатною навіть побутова відеокамера $з$ достатньою світлочутливістю та функцією наближення. Випробуйте камеру в умовах епізоду 3 найгіршим освітленням (зйомки у погано освітленому приміщенні). Знімайте принаймні двома дублями, щоб в подальшому мати достатню кількість відеоматеріалу та вибрати найбільш вдалі плани для монтажу окремих епізодів. За нашою практикою, чернетковий відеоматеріал для 20-хвилинного фільму складає 50-60 хвилин. Уникайте занадто довгих статичних планів у надії заповнити їх розлогим коментарем, оскільки завдання таких відеофільмів - тільки закріпити навчальний матеріал із залученням візуальної пам'яті.

Озвучування. При необхідності включити у фільм живий коментар дійової особи обов'язково перевірте якість звуку при адаптуванні файлу у монтажну комп’ютерну програму, оскільки мікрофони більшості побутових камер не розраховані на запис студійної якості. Аудіозапис тексту коментарів краще проводити в умовах повної тиші, використовуючи вокальний або студійний мікрофон. Швидкість зачитування тексту та його тривалість залежать від тривалості конкретного відеоепізоду і має бути на 15-20 \% меншим за нього, тому зручно проводити звукозапис після монтажу відеоряду. Паузи, що утворились між епізодами, можна заповнити заздалегідь підготованою мелодійною фонограмою, яка може тривати на комфортній гучності (не заважаючи сприйняттю коментаря та відеоряду) протягом усього фільму.

Монтаж. Монтаж - найскладніший процес у медіа-виробництві, який не можливий без персонального комп’ютера та відповідних навичок. Щоб перевести аналогову медіа-інформацію у цифрову, також знадобиться спеціальна плата аудіо-відео захоплення. Для швидкого та безпроблемного зведення аудіо та відео бажано використовувати мультиформатне програмне забезпечення, наприклад Grass Valley EDIUS ${ }^{\circledR}$. У всесвітній мережі можна з легкістю знайти книжки або відеоуроки з детальним описом роботи з програмним забезпеченням для монтажу. Розклавши отримані відео- та аудіопотоки на монтажному “столі”, починаємо їх зведення згідно зі сценарієм, використовуючи кадрування та за необхідністю, численні спеціальні ефекти, які $є$ в арсеналі подібних програм. Також важливо зробити якісні титри, не пропустивши жодного 3 
учасників виробництва навчального фільму, що $є$ загальною практикою останнього часу. Вихідний медіа-контент радимо покласти у один з найпоширеніших мультимедійних контейнерів - AVI.

Демонстрація. Щоб уникнути проблем під час демонстрації фільму на кінцевому обладнанні, перегляньте його заздалегідь. Щоб перегляд фільму був більш комфортним, використовуйте незначне затемнення приміщення, великий екран та якісну акустичну систему.

\section{Список літератури}

1. Закон України “Про вищу освіту” // Відомості Верховної Ради (ВВР). - 2014. - № 37-38. - Ст. 2004.
Висновки: 1. В умовах зростання інформаційного навантаження на студентів медичних вищих навчальних закладів з одночасним скороченням аудиторних годин, використання допоміжних аудіовізуальних засобів навчання має значно полегшити засвоєння складних тем, що вимагають додаткових знань з суміжних та непрофільних дисциплін.

2. Створення навчальних відеофільмів з гігієни силами профільних кафедр може бути більш вдалим з урахуванням практичних рекомендацій, що викладені у статті.

2. http://osvita.ua/school/lessons_summary/proftech/ 34663/.

Отримано 27.07.15 